\title{
STRATEGI DAN OPERASIONAL PENGEMBANGAN AGROINDUSTRI BERKELANJUTAN RUMPUT LAUT DI INDONESIA
}

\author{
Strategy and Operations of Seaweed Sustainable Agro-Industry Development in Indonesia \\ Kartika \\ Program Studi Teknologi Pangan, Fakultas Teknik \\ Universitas Islam Al-Ihya Kuningan, Jawa Barat, Indonesia \\ E-mail: kartikarofiq@gmail.com
}

\begin{abstract}
ABSTRAK
Rumput laut merupakan komoditas strategis dalam bidang kelautan Indonesia. Berdasarkan data yang dikeluarkan oleh Kementerian Kelautan dan Perikanan Indonesia dan DKP, potensi pengembangan agroindustri rumput laut di Indonesia sangat besar. Namun pengembangan agroindustri rumput laut ini masih banyak memiliki kendala seperti, kualitas rumput laut yang dihasilkan rendah dan tidak seragam, harga rumput laut yang tidak stabil, dan menghasilkan limbah yang besar dan berpotensi mencemari lingkungan sekitar. Oleh sebab itu, dibuatlah konsep pengembangan klaster agroindustri rumput laut berkelanjutan yang merupakan salah satu upaya dalam rangka meningkatkan daya saing rumput laut secara berkelanjutan, sekaligus upaya dalam mengatasi berbagai permasalahan yang dihadapi industri rumput laut Indonesia selama ini.
\end{abstract}

Kata kunci: rumput laut, klaster, agroindustri, berkelanjutan

\begin{abstract}
Seaweed is a strategic commodity in the Indonesian marine sector. Based on data released by the Indonesian Ministry of Maritime Affairs and Fisheries and the DKP, the potential for seaweed agroindustry development in Indonesia is huge. However, the development of seaweed agro-industry still has many obstacles such as, the quality of seaweed wich are produced is low and not the same, the price of seaweed is unstable, and the process produces large waste and has the potential to pollute the surrounding environment. Therefore, the concept of sustainable seaweed agro-industry cluster development was made, which is one of the efforts in order to increase the competitiveness of seaweed sustainability, as well as efforts to overcome various problems faced by the Indonesian seaweed industry so far.
\end{abstract}

Keywords: seaweed, cluster, agro-industry, sustainable

\section{PENDAHULUAN}

Indonesia merupakan negara kepulauan dengan luas laut mencapai 5,8 juta $\mathrm{km}^{2}$ dan panjang garis pantai mencapai $95.181 \mathrm{~km}$, serta jumlah pulau sebanyak 17.504 pulau (KKP 2009). Indonesia memiliki potensi sumberdaya yang cukup besar, terutama sumberdaya perikanan laut baik dari segi kuantitas maupun diversitas dengan sejumlah keunggulan komparatif sekaligus kompetitif yang sangat tinggi (Dahuri 2003). Sebagai negara kepulauan, Indonesia diharapkan mampu memanfaatkan dan mengembangkan sumberdaya hayati laut sebaik-baiknya, termasuk diantaranya adalah pengembangan komoditas rumput laut (seaweed). Rumput laut merupakan salah satu komoditas strategis dalam bidang kelautan disamping udang dan tuna. Berdasarkan data Kementerian Kelautan dan Perikanan, Indonesia memiliki luas area untuk kegiatan budidaya rumput laut mencapai 1.110 .900 ha, tetapi pengembangan budidaya rumput laut baru memanfaatkan lahan seluas 222.180 ha atau $20 \%$ dari luas areal potensial. Hal ini menunjukkan bahwa masih terbuka peluang untuk mengembangkan usaha budidaya rumput laut di Indonesia. 
Potensi lahan pengembangan budidaya rumput laut tersebar di seluruh wilayah Indonesia dimana sebagian besar potensi berada di daerah Papua, Maluku, Sulawesi Tengah, Nanggroe Aceh Darussalam, Sulawesi Tenggara, Sulawesi Selatan, Jawa Timur, dan Bali (DKP 2005). Jenis rumput laut yang dikembangkan di Indonesia antara lain adalah Kappaphycus alvarezii (cottonii), Eucheuma denticulatum (spinosum) dan Gracilaria sp.

Meskipun saat ini Indonesia merupakan negara produsen rumput laut penghasil karaginan terbesar di dunia, namun peran dan kontribusi Indonesia dalam industri pengolahan rumput laut masih perlu ditingkatkan mengingat peluangnya masih cukup besar. Dengan dicanangkannya revitalisasi pembangunan kelautan Indonesia dimana rumput laut menjadi salah satu komoditas utama yang direvitalisasi, industri pengolahan rumput laut berkembang cukup pesat. Orientasi pemanfaatan rumput laut sebagai komoditas ekspor dalam bentuk raw material saat ini sudah mulai bergeser menjadi produk yang memiliki nilai tambah tinggi, khususnya dalam bentuk ATC (alkali treated cottonii). ATC merupakan suatu produk karaginan semi jadi yang berasal dari proses pengolahan rumput laut Eucheuma cottonii yang pada umumnya digunakan sebagai pengatur keseimbangan, pengental, pembentuk gel, dan pengemulsi dalam industri pangan dan non pangan. Dengan berkembangnya industri ATC ini tentunya diharapkan dapat meningkatkan nilai ekspor produk kelautan Indonesia ke luar negeri. Hal ini akan membawa dampak positif bagi seluruh pihak yang terlibat dalam mata rantai penciptaan nilai tambah rumput laut (value adding chain).

\section{KENDALA DALAM PENGEMBANGAN AGROINDUSTRI RUMPUT LAUT INDONESIA}

Dalam rangka meningkatkan daya saing industri rumput laut di Indonesia, maka penguatan struktur industri rumput laut nasional perlu segera dilakukan. Hal ini disebabkan meskipun Indonesia menjadi produsen rumput laut terbesar di dunia, namun harga bahan baku masih dikendalikan oleh pembeli dari luar negeri (buyer market). Strategi pengembangan industri rumput laut masih kurang terencana dengan baik. Strategi belum dirancang menjadi suatu struktur usaha yang dikelola dan berorientasi pada pengembangan industri dari hulu sampai hilir dan turunannya, sehingga sangat rentan terhadap perubahan.

Pada sisi yang lain, secara internal industri rumput laut didalam negeri masih menghadapi berbagai kendala pada hampir semua segmen, khususnya di tingkat pembudidaya dan industri pengolahan. Beberapa permasalahan yang menonjol diantaranya terkait dengan: (i) kualitas rumput laut yang dihasilkan pembudidaya umumnya masih rendah karena teknik budidaya dan penanganan pascapanen belum dilakukan secara benar, yang mengakibatkan industri pengolahan kesulitan dalam memproduksi produk akhir yang sesuai dengan standar mutu internasional; (ii) industri pengolahan tidak mendapatkan jaminan pasokan bahan baku yang tepat jumlah, mutu, waktu dan harga, karena rumput laut menjadi komoditas dagang dan lebih banyak dijual dalam bentuk rumput laut kering; (iii) harga rumput laut sering tidak rasional sebagai bahan baku industri karena tidak ada tata niaga yang terkoordinir dengan mengacu kepada norma industri dengan banyaknya spekulan bahan baku (DKP 2005); serta (iv) industri pengolahan menghasilkan limbah yang sangat besar yang berpotensi mencemari lingkungan sekitar (Sedayu et al. 2007).

\section{PENGEMBANGAN KLASTER INDUSTRI RUMPUT LAUT}

Berdasarkan pada kondisi-kondisi tersebut, maka langkah yang perlu segera dilakukan adalah memprogramkan penguatan struktur industri rumput laut nasional dari hulu ke hilir. Terkait dengan hal tersebut, salah satu strategi yang dapat dilakukan adalah melalui pendekatan klaster industri. Pendekatan ini akan mendorong penguatan hubungan antar industri rumput laut yang saling terkait dalam rantai proses peningkatan nilai tambah. Merujuk pada pendapat (Taufik 2005), dalam klaster industri rumput laut, industri terdiri dari himpunan para pelaku dalam konteks tertentu baik yang berperan sebagai industri inti, pemasok kepada pelaku industri inti, industri pendukung bagi industri inti, serta pihak atau lembaga yang memberikan jasa layanan kepada pelaku industri inti. 
Penerapan pendekatan klaster industri dilakukan untuk lebih mendayagunakan dan mengembangkan industri rumput laut Indonesia sehingga menjadi usaha yang terintegrasi dan handal mulai dari hulu hingga hilir serta berdaya saing tinggi. Program penguatan struktur industri rumput laut berbasis klaster dilakukan melalui sinergi dan koordinasi dari berbagai pihak, baik antar kementerian terkait dari pihak pemerintah, maupun para pelaku usaha di pihak lain seperti pembudidaya, pedagang, eksportir, dan industri pengolah, termasuk di dalamnya lembaga keuangan bank dan non bank. Keterlibatan para pemangku kepentingan ini akan menjadi kunci keberhasilan pencapaian dalam pengembangan industri rumput laut nasional secara berkelanjutan.

Pengembangan klaster industri rumput laut diharapkan mampu menciptakan manfaat ekonomi dan daya saing. Namun demikian, tantangan yang dihadapi dalam pengembangan klaster industri rumput laut saat ini sangat kompleks untuk mewujudkan klaster industri rumput laut secara berkelanjutan. Argumentasi yang melandasinya adalah bahwa praktek-praktek pembangunan ekonomi berbasis klaster yang selama ini dilakukan telah mengabaikan faktor-faktor keberlanjutan yang cenderung hanya bertujuan untuk merealisasikan potensi pengembangan ekonomi semata. Tantangan yang dihadapi bagi pengembang klaster saat ini tidak hanya terfokus pada aspek ekonomi, tetapi juga terkait dengan aspek lingkungan dan sosial. Pengembangan klaster industri rumput laut yang berkelanjutan merupakan salah satu upaya dalam rangka meningkatkan daya saing industri rumput laut secara berkelanjutan sekaligus sebagai upaya dalam mengatasi berbagai permasalahan yang dihadapi industri rumput laut di Indonesia selama ini. Dalam konteks ini, tidak hanya manfaat ekonomi yang menjadi tujuan dalam pengembangan klaster industri rumput laut, melainkan juga manfaat lingkungan dan sosial yang perlu diperhatikan secara seimbang.

Rancang bangun model pengembangan klaster industri rumput laut yang berkelanjutan dikembangkan oleh (Wibowo 2011), menghasilkan SPK KlasteRula yang dapat digunakan untuk mendukung keputusan dalam perencanaan pengembangan klaster industri rumput laut yang berkelanjutan secara efektif. Hasil implementasi model menunjukkan bahwa pengembangan klaster industri rumput laut mampu mendorong tercapainya keberlanjutan klaster, baik keberlanjutan pada aspek ekonomi, sosial, maupun lingkungan. Indikasi ini terlihat dari hasil prediksi pengukuran kinerja pengembangan klaster. Pada aspek ekonomi, pengembangan klaster industri rumput laut mampu mendorong peningkatan keuntungan pelaku usaha yang terlibat didalam klaster. Dengan meningkatnya kerjasama antar pelaku usaha yang semakin intensif didalam klaster akan mendorong meningkatnya kualitas produk yang dihasilkan yang berdampak pada meningkatnya harga pada seluruh rantai usaha yang terlibat didalam klaster (Martin et al. 2008). Nilai tambah yang diperoleh dalam pengembangan klaster industri rumput laut sebagian besar dinikmati oleh pembudidaya secara agregat sesuai dengan kapasitas produksi klaster, kemudian disusul agroindustri, kelompok pembudidaya dan koperasi.

Pada aspek sosial, pengembangan klaster industri rumput laut mampu mendorong penyerapan jumlah tenaga kerja, khususnya tenaga kerja pada usaha budidaya rumput laut. Jumlah tenaga kerja yang terserap didalam klaster berbanding lurus dengan jumlah kapasitas produksi yang ditetapkan didalam klaster. Jumlah tenaga kerja yang terserap akan semakin bertambah dengan meningkatnya kapasitas produksi klaster. Pada aspek lingkungan, pengembangan klaster industri rumput laut mampu menekan potensi pencemaran lingkungan yang disebabkan limbah cair yang dihasilkan oleh agroindustri rumput laut (ATC) melalui proses daur ulang (recycle). Proses daur ulang limbah cair juga mampu meningkatkan efisiensi penggunaan air dalam proses pengolahan ATC dengan pemakaian kembali air yang telah didaur ulang untuk proses produksi. 


\section{SISTEM LOGISTIK DAN KEBERLANJUTAN AGROINDUSTRI RUMPUT LAUT}

Sistem logistik rumput laut berbasis entitas sistem di Sulawesi Selatan dan pendapat ahli membagi sistem logistik menjadi tiga subsistem yaitu entitas subsistem pengadaan ((procurement), subsistem logistik internal (plant site), entitas subsistem logistik produk olahan rumput laut (finish good). Subsistem pengadaan bahan baku terdiri dari panen dan pasca panen, transportasi bahan baku, kontrol kualitas, penyimpanan bahan baku, pengadaan bahan baku rumput laut untuk proses produksi industri dan serah terima bahan baku. Proses utama pada subsistem logistik internal adalah penyimpanan bahan baku, proses produksi produk setengah jadi, pengemasan produk setengah jadi, pengiriman produk setengah jadi, penyimpanan bahan baku (produk setengah jadi) pada gudang pabrik produk jadi, proses produksi produk jadi, pengemasan produk jadi dan pengiriman produk jadi. Subsistem logistik produk olahan rumput laut (finish good) terdiri dari lima lane proses bisnis yang terdiri atas proses penyimpanan produk, transportasi produk, pemasaran produk, ekspor produk, dan pengemasan distribusi (Sarinah 2018).

Keberlanjutan klaster industri rumput laut sangat ditentukan oleh ketersediaan rumput laut sebagai bahan baku utama didalam klaster. Rumput laut harus dapat diproduksi secara massal, kontinyu, dan seragam untuk memenuhi kebutuhan bahan baku bagi agroindustri rumput laut didalam klaster. Untuk meningkatkan akurasi model terkait dengan perencanaan penyediaan bahan baku, maka perlu dirancang suatu model yang mampu mengakomodasi standarisasi proses produksi rumput laut, dengan mempertimbangkan faktor spasial, temporal, dan risiko, sehingga dapat menghasilkan rumput laut secara tepat kuantitas, tepat kualitas, dan tepat waktu pada saat dibutuhkan. Untuk menganalisis lebih jauh tentang efisiensi dan produktivitas klaster industri, maka perlu dirancang suatu model yang lebih komprehensif terkait dengan manajemen rantai pasok mulai dari proses hulu hingga hilir yang melibatkan para pelaku usaha didalam klaster. Model manajemen rantai pasok akan memberikan informasi yang akurat tentang aliran material produksi pada setiap tingkatan dalam rantai produksi didalam klaster, termasuk perhitungan waktu tunda yang mungkin terjadi pada setiap rangkaian proses produksi.

\section{KESIMPULAN}

Indonesia memiliki potensi yang sangat besar dalam mengembangkan industri rumput laut. Namun pengembangan agroindustri rumput laut ini masih banyak memiliki kendala seperti, kualitas rumput laut yang dihasilkan rendah dan tidak seragam, harga rumput laut yang tidak stabil, dan menghasilkan limbah yang besar dan berpotensi mencemari lingkungan sekitar. Oleh sebab itu, dibuatlah konsep pengembangan klaster agroindustri rumput laut berkelanjutan yang merupakan salah satu upaya dalam rangka meningkatkan daya saing rumput laut secara berkelanjutan, sekaligus upaya dalam mengatasi berbagai permasalahan yang dihadapi industri rumput laut Indonesia selama ini.

\section{UCAPAN TERIMAKASIH}

Penulis ingin menyampaikan terima kasih kepada Prof. Dr. Ir. Anas Miftah Fauzi, M.Eng yang telah memberikan banyak masukan dalam penulisan artikel ini.

\section{DAFTAR PUSTAKA}

Dahuri R. (2003). Paradigma Baru Pembangunan Indonesia Berbasis Kelautan. (Orasi IImiah). Guru Besar Tetap Bidang Pengelolaan Sumberdaya Pesisir dan Lautan Fakultas Perikanan dan IImu Kelautan Institut Pertanian Bogor, Bogor.

Departemen Kelautan dan Perikanan (DKP). (2006). Program Revitalisasi Perikanan Bidang Pengolahan dan Pemasaran. Direktorat Jenderal Pengolahan dan Pemasaran Hasil Perikanan Departemen Kelautan dan Perikanan, Jakarta. 
Kementerian Kelautan dan Perikanan (KKP). (2009). Kelautan dan Perikanan Dalam Angka 2009, Kementerian Kelautan dan Perikanan, Jakarta.

Martin S, Mayer H. (2008). Sustainability, Clusters, and Competitiveness: Introduction to Focus Section. Economic Development Quarterly 2008 (22): 272.

Sarinah. (2018). Desain Model Strategi Logistik pada Agroindustri Rumput Laut di Sulawesi Selatan. (Disertasi). Program Studi Teknologi Industri Pertanian Sekolah Pascasarjana Institut Pertanian Bogor, Bogor.

Sedayu BB, Basmal J, Fithriani D. (2007). Uji Coba Proses Daur Ulang Limbah Cair ATC (Alkali Treated Cottonii) dengan Teknik Koagulasi dan Filtrasi. Jurnal Pascapanen dan Bioteknologi Kelautan dan Perikanan Vol. 2 Desember 2007 (2): 107-115.

Taufik TA. (2005). Penguatan Daya Saing dengan Platform Klaster Industri: Prasyarat Memasuki Ekonomi Baru. Makalah disampaikan dalam Strategi dan Implementasi Pengembangan Daya Saing Ekonomi Daerah dengan Pendekatan Lintas Sektoral Core Competence dan PUPUK, 9 Februari 2005, Yogyakarta.

Wibowo Y. (2011). Rancang Bangun Model Pengembangan Klaster Industri Rumput Laut yang Berkelanjutan. (Disertasi). Program Studi Teknologi Industri Pertanian Sekolah Pascasarjana Institut Pertanian Bogor, Bogor. 